\title{
JUDICIAL REVIEW AND FEDERALISM
}

\author{
JOHN C. YOO*
}

The "political safeguards" theory of federalism posits that the judiciary should not intervene to protect the states from unconstitutional encroachment by the federal government. Rather, it argues, the sole recourse and means of protection provided to the states by the Constitution lies in the national political process.

The Supreme Court adopted the political safeguards theory in Garcia v. San Antonio Metropolitan Transit Authority. ${ }^{1}$ The Framers, however, did envision a role for the courts in preserving the balance between state and federal power. Indeed, since Garcia was decided, the Court has rediscovered its proper role in preserving the federalist structure, striking down encroaching federal legislation on several occasions. ${ }^{2}$ The continuing vigilance of the courts in protecting states' rights is of critical importance if the state-federal balance of power so necessary to the preservation of our liberty is to be maintained.

I

Viewing this theory from an original understanding perspective, the question of whether the political process was to be the sole guardian of the federalist structure has a clear answer. The Framers believed in the political safeguards of federalism, but they did not believe that political safeguards were exclusive. The Framers treated states' rights in much the same way as they treated individual rights. Although they believed that the national government would restrain itself

\footnotetext{
* Acting Professor of Law, University of California School of Law (Boalt Hall). The substance of this talk is drawn from a previously published article. See John C. Yoo, The Judicial Safeguards of Federalism, 70 S. CAL. L. REV. 1311 (1997).

1. 469 U.S. 528, 550-51 (1985) (holding that Congress has the power under Article I, § 8 Commerce Clause to apply the provisions of the Fair Labor Standards Act to state employees).

2 See e.g., Printz v. United States, 117 S.Ct. 2365 (1997); Seminole Tribe v. Florida, 517 U.S. 44 (1996); United States v. Lopez, 514 U.S. 549 (1995).
} 
from violating individual rights, the Framers fully anticipated that the courts would exercise judicial review to back up the political process. ${ }^{3}$ The protection of the federalist structure was viewed similarly, and the ratification debates reflect the Framers' consensus on this point. 4

As a methodological matter, the ratification debates are far more important for interpretive purposes than the Philadelphia convention. ${ }^{5}$ The Philadelphia convention amounted to a group of well-meaning politicians in a secret room. The delegates created a document that had no political force and no legitimating value. The state ratification conventions, where the states actually adopted the Constitution, produced the legislative history that really matters. They are the events that have political meaning in the adoption of the Constitution. Indeed, James Madison, himself, noted the preeminent significance of the state ratification conventions during the First Congress. ${ }^{6}$ The Philadelphia Convention was akin to the proceedings of an interest group that drafts legislation. The state ratification debates serve the same role as the Congressional Record in parsing legislation.

Furthermore, the ratification debates occurred over a great expanse of distance and a long period of time. One cannot read the debates as though the conventioneers pulled out a few arguments and, through the course of debate, concluded that one argument was more important than another. Instead, the debates must be read as a political dialogue similar to those we have today-where people respond to arguments, and the arguments change over time as the different sides respond to each other and raise new points.

The political-safeguards argument emerged very early in this process. Anti-Federalists claimed that the central government would be all-encompassing, seize power, and oppress the states as England had oppressed the colonies.7 Much of the

3. See THE FEDERALIST No. 78, at 524 (Alexander Hamilton) Jacob E. Cooke ed, 1961).

4. See John C. Yoo, The Judicial Safeguards of Federalism, 70 S. CAL. L. REv. 1311, 13741405 (1997).

5. See, e.g., LEONARD LEVY, ORIGINAL INTENT AND THE FRAMERS' CONSTITUTION 1-29 (1988); JACK N. RAKOVE, ORIGINAL MEANINGS: POLIIICS AND IDEAS IN THE MAKING OF THE CONSTITUTION 8 (1996).

6. See 5 ANNALS OF CONG. $487-95$ (1796).

7. See Yoo, supra note 4 , at $1375-77$. 
logic used by the Anti-Federalists is very similar to the antiinside-the-beltway rhetoric heard today. The most prominent Anti-Federalist writer, Brutus, ${ }^{8}$ a great republican, argued that Congress simply could not be trusted to restrain itself. Drawing upon the lessons of history, he asserted that whenever a group of people had been given power, that group had continuously tried to expand its power until stopped. 9 Such, Brutus argued, was the nature of man.

The Federalist No. 45 was designed to respond to this argument. ${ }^{10}$ Madison wrote that "each of the principal [sic] branches of the federal Government will owe its existence more or less to the favor of the State Governments, and must consequently feel a dependence, which is more likely to beget a disposition too obsequious, than too overbearing towards them."11 Other proponents of ratification argued that the national government could be trusted not to attempt to annihilate the states, because Congress was responsible to the states through the Senate, whose membership was elected by the state legislatures.12 These arguments did not convince the Anti-Federalists, who mounted a vigorous attack and came close to defeating the Constitution in several of the major states. 13

Brutus also advanced other arguments against adopting the Constitution. He openly wondered whether the terms of the Constitution were sufficiently definite to be understood and obeyed in the same way by everyone. He answered his own question, saying that no one would pretend that everyone would interpret the terms of the Constitution in the same manner. ${ }^{14}$ In reference to the General Welfare Clause, ${ }^{15}$ he

8. There was no Caesar around to kill at that point, but the political writers of the founding period had a penchant for classical noms de plume.

9. See Brutus I, N.Y. J., Oct. 18, 1787, reprinted in 13 THE DOCUMENTARY HISTORY OF THE RATIFICATION OF THE CONSTITUTION 416-17 (John P. Kaminski \& Gaspare J. Saladino eds., 1981).

10. The Federalist Papers did not come out all at once in an easy-to-read version. They were actually written in response to specific Anti-Federalist arguments.

11. THE FEDERALIST No. 45, at 311 (James Madison) (Jacob E. Cooke ed., 1961).

12 See, e.g., James Wilson, Speech at a Public Meeting (Oct. 6, 1787), in 1 THE DEBATE ON THE CONSTITUTION 67 (Bernard Bailyn ed., 1993).

13. See e.g., James Madison, Letter to Governor Edmund Randolph (Jan. 10, 1788), reprinted in 1 THE DEBATE ON THE CONSTITUTION, supra note 12, at 744-47 (Madison expresses his concerns that a second convention would give opponents the opporturity to defeat ratification of the Constitution).

14. See Brutus VI, N.Y. J., Dec. 27, 1787, reprinted in 1 THE DEBATE ON THE 
predicted that the extent of federal power would come down to a matter of opinion as to what tends to the general welfare. Brutus ominously predicted that the government would always say that its measures were designed to promote the public good. ${ }^{16}$ This broad interpretation of federal power, he argued, would gain ascendancy, because if there were no judge between the Congress and the people, the rulers would always judge for themselves.

This is a very powerful argument against the political safeguards theory of federalism. Notably, it is only at this point in the ratification debates that arguments about judicial review appear. ${ }^{17}$ Talk of judicial review first emerges in the context of a discussion about federalism, and judicial review is portrayed as a fundamental check against the central government. ${ }^{18}$

The Federalist No. 78 is often presented as the primary text to defend the use of judicial review to protect individual rights. ${ }^{19}$ The Constitution that was being debated, however, guaranteed very little in the way of individual rights; the Bill of Rights would not become part of the Constitution for three more years. The Federalist No. 78 cannot be fully understood unless read in the context of a debate about the powers of the national government vis-à-vis the states. This context gives fuller meaning to passages like the following: "If it be said that the legislative body [sic] are themselves the constitutional judges of their own powers, and that the construction they put upon them is conclusive upon the other departments, it may be answered, that this cannot be the natural presumption, where it is not to be collected from any particular provisions in the constitution." 20 Soon after that passage comes the classic statement that interpretation of laws is the proper and peculiar province of the courts. ${ }^{21}$

CONSTITUTION, supra note 12, at 618.

15. U.S. CONST. art. I, $\$ 8$.

16. See Brutus VI, N.Y. J., Dec. 13, 1787, reprinted in 1 THE DEBATE ON THE CONSTTUTION, supra note 12, at 500 .

17. See, e.g., THE FEDERALIST No. 46, at 320 (James Madison) (Jacob E. Cooke ed., 1961); John Stevens, Jr., Americanus VII, DARY ADVERTISER, Jan. 21, 1788, reprinted in 2 THE DEBATE ON THE CONSTITUTION, supra note 12, at 60; James Wilson, Remarks at the Pennsylvania Ratifying Convention (Dec. 1, 1787), in 1 THE DEBATE ON THE CONSTITUTION, supra note 12, at 822-23.

18. See Yoo, supra note 4, at 1386-87.

19. See THE FEDERALIST NO. 78 (Alexander Hamilton).

20. Id. at 524-25 (Jacob E. Cooke ed., 1961).

21. See id. at 525. 
This argument appears not only in The Federalist No. 78. It was also made by Oliver Ellsworth, who wrote the Judiciary Act of 1789.22 In response to the Anti-Federalist's claims, he replied that if the general legislature should at any time overstep its limits, the judicial department would provide a constitutional check. ${ }^{23}$ John Marshall, responding to the same anti-federalist arguments at the Virginia ratifying convention, stated that "[i]f [Congress] were to make a law not warranted by any of the powers enumerated, it would be considered by the Judges as infringement of the Constitution which they are to guard:-They would not consider such a law as coming under their jurisdiction.-They would declare it void." 24

Throughout the ratification debates, judicial review was cast by the Federalists as a necessary buttress to the political safeguards of federalism. The political safeguards are not, nor were they intended to be, exclusive. Political safeguards and judicial review were seen as complementing and supplementing one another, just as they did with respect to individual rights.

II

It might be useful to recall the theory behind the politicalsafeguards view of federalism adopted by Garcia. ${ }^{25}$ The idea that the national political process will protect states' rights was explicitly normative, not descriptive. The Garcia Court did not say that it was adopting the political safeguards theory because it had observed that it worked that way in real life. ${ }^{26}$ In writing

22. 1 Stat. 73 (1789); see also DAVID P. CURRIE, THE CONSTITUTION IN CONGREsS 47 (1997).

23. Oliver Ellsworth, Remarks at the Connecticut Ratifying Convention (Jan. 7, 1788), in 1 THE DEBATE ON THE CONSTITUTION, supra note 12, at 883.

24. John Marshall, Remarks at Virginia Ratifying Convention (June 20, 1788), in 2 THE DEBATE ON THE CONSTITUTION, supra note 12, at732

25. Garcia v. San Antonio Metro. Transit Auth., 469 U.S. 528 (1985).

26. The Court did note that "[t]he effectiveness of the federal political process in preserving the States' interests is apparent even today in the course of federal legislation." Id. at 552. The Court's only evidence of the success of the political process in safeguarding federalism, however, was the exemption of states from a handful of generally applicable statutes and the fact that the federal government gives grants to states and localities. See id. at 552-53. The Court indicated that it was relying on a normative rather than a descriptive vision of the political safeguards of federalism when it admitted without further analysis that the safeguards that had been built into the system at its inception were eroded by the Seventeenth Amendment's transformation of the Senate into a popularly elected body. See id. at 554 
their articles about the political safeguards of federalism, Herbert Wechsler and Jesse Choper explicitly argue that the normative value of the political-safeguards theory is that it would allow the Court to focus primarily on protecting individual rights, which they decided was more important than protecting constitutional structure. ${ }^{27}$

Moreover, the Court either will overrule Garcia in the next few years or already has overruled it sub silencio. For instance, in Gregory v. Ashcroft, ${ }^{28}$ the Court interpreted a statute in a manner that avoided regulating state employees, because it felt that the regulation of state employees by the federal government would raise a political question. ${ }^{29}$ Such a construction would be unnecessary if Garcia were still good law; under Garcia, it is not a justiciable question whether the federal government can regulate the retirement age of state judges. Similarly, the Court in New York v. United States ${ }^{30}$ and Printz v. United States ${ }^{31}$ would not have reached the same results had the Court believed the states' primary-if not only-remedy for federalism violations was relying upon the political process.

\section{III}

Lastly, one must consider the normative value of federalism. Many arguments in favor of federalism, such as decentralization, responsiveness to local populations, and competition for citizens and business, can just as easily be accomplished with only ten states or six. Why do we need fifty? Why do we not have administrative subdivisions of the

27. See JESSE H. CHOPER, JUdICIAL REVIEW AND THE NATIONAL POLITICAL PROCESS 169 (1980); Herbert Wechsler, The Political Safeguards of Federalism: The Role of the States in the Composition and Selection of the National Government, 54 COLUM. L. REv. 543, 546 (1954). Choper and Wechsler argue that the institutional structure of the Court renders it the best-suited branch of the federal government to protect individual rights but poorly suits it to resolve issues of federalism and the separation of powers. Believing that the Court possesses exhaustible institutional capital, Choper concludes that the Court should focus on protecting the rights of those who have no resort to the democratic political process. See Yoo, supra note 4, at 1318-21.

28. 501 U.S. 452 (1991) (holding that Missouri's mandatory retirement provision for state judges did not violate the Age Discrimination Employment Act of 1967).

29. Id. at 464 .

30. 505 U.S. 144 (1992) (holding, in the context of the Low-Level Radioactive Waste Policy Amendments Act of 1985, that Congress cannot directly compel the states to enact and enforce a federal regulatory program).

31. 117 S. Ct. 2365 (1997) (holding that a provision of the Brady Handgun Violence Prevention Act compelling state officers to execute federal law is unconstitutional). 
national government? What, in the final analysis, is the normative purpose of federalism?

Looking at the history of the Constitution, one thing becomes clear. The Framers believed that federalism was necessary to create a certain inefficiency in government. Inefficiency is a well-accepted objective of the separation of powers. When it comes to federalism, however, the states are seen as the great enemy of effective national policy. It is forgotten that the resulting inefficiency was the entire point of establishing a federal system. The states were supposed to prevent the national government from doing bad things, as well as good. This is the trade-off necessary for achieving the value of inefficiency.

That is why Justices $\mathrm{O}^{\prime}$ Connor and Kennedy have repeatedly proclaimed that, out of the contest or tension between national and state governments, liberty results. ${ }^{32}$ It is a nice rhetorical phrase, although they never really explain how it is that liberty results. The idea of a liberal state, at least in the 18th Century, was to create liberty through the absence of government regulation in most areas of life. This left things to the marketplace or to private social arrangements. Federalism was conceived of as the fundamental cornerstone of the Founders' liberal republic. Only by maintaining our nation's federal structure can we secure the fundamental freedoms of mankind, which we have gratefully inherited and must tirelessly protect.

32 See, e.g., Gregory, 501 U.S. at 458-59 (O'Connor, J.) ("Just as the separation and independence of the coordinate branches of the Federal Government serve to prevent the accumulation of excessive power in any one branch, a healthy balance of power between the States and the Federal Government will reduce the risk of tyranny and abuse from either front .... In the tension between federal and state power lies the promise of liberty"); United States v. Lopez, 514 U.S. 549, 576 (1995) (Kennedy, J., concurring) (quoting Gregory). 
HeinOnline -- 22 Harv. J. L. \& Pub. Pol'y 204 1998-1999 